\title{
viewpoint
}

\section{Signals and noise}

\section{M ass-media coverage of climate change in the USA and the UK}

\section{MaxudIT. Boykoff\&S. Ravi Rajan}

$\mathrm{H}$ ow the mass media cover scientific subjects matters in many ways, whether scientists like it or not. Stem cells, genetically modified organisms, cloning, the environmental or health implications of chemicals or climate change: whatever the subject, media coverage has helped to shape public perception and, through it, affected how science is translated into policy, most notably in regard to the environment, new technologies and risks (Weingart et al, 2000). Conversely, political, economic and other interests have long tried to influence media coverage of particular topics to affect the public's understanding and perception, and scientists are now becoming more aware of the power of the media. Consequently, the intersection of mass media, science and policy is a particularly dynamic arena of communication, in which all sides have high stakes.

The integral role played by the media is not surprising, as it is still the main source of information and opinion for millions of readers and viewers-and voters- through newspapers, magazines, television, radio and the internet. As people gain most of their political, economic or other news from the media, so they do with scientific stories. Various studies have shown that the public gathers much of its knowledge about science from the mass media (Wilson, 1995), with television and daily newspapers being the primary sources of information (Project for Excellence in Journalism, 2006; N SF, 2004). Given their wide reach, it is therefore important to investigate the media's coverage of scientific topics and how it influences both science and policy. In this viewpoint, we survey the media's portrayal of climate science and man-made climate change-dubbed 'global warming', or anthropogenic climate change-and its coverage in the USA and UK as an important example of how science, politics and the media intersect and interact. More specifically, we explore how external influences and internal factors shape and define media coverage of climate science.

$\mathrm{R}$ esearch into anthropogenic effects on climate change can be traced back as far as the eighteenth century, when researchers investigated the relationship between deforestation and precipitation (Rajan, 2006; Grove, 2003), the link between variations in brightness of the sun or sunspots and temperature changes on Earth, and how specific gases in the atmosphere influence the temperature on Earth (Weart, 2003). By the late nineteenth century, researchers began to look more specifically into the role of humans in climate change. In 1896, the Swedish chemist Svante Arrhenius speculated whether and how carbon dioxide emissions could lead to increases in atmospheric temperature and a 'greenhouse effect' (Fleming, 1998).

At this time, the mediamainly newspapers-were at the early stages of rapid and large changes. Their reach was still limited by various constraints, such as state control over the public sphere, legacies of colonialism, low literacy rates and technological limitations (Starr, 2004). However, increasing literacy and the invention of mass-circulation print presses tremendously expanded their reach and influence in both the USA and the UK, when newspapers, at least in urban centres, became available for a few pennies. Their wider reach, coupled with advertising revenue, also meant that newspapers became more economically attractive, which resulted in a development from small papers to large news businesses. Indeed, the late nineteenth and early twentieth centuries saw the rise of the first media conglomerates, exemplified by US newspaper magnates Joseph Puliter and William Randolph

Hearst. As a consequence of these developments, the media became increasingly powerful social, political, economic and cultural institutions that were entrenched in society (McChesney, 1999; D oyle 2002).

The two spheres of climate science and mass media finally came together in the early 1950s. In the UK, the Saturday Evening Post published a story entitled 'Is the World Getting W armer?', which explored links between atmospheric temperature change, agricultural shifts and rising sea levels (Abarbanel \& McClusky, 1950). Media coverage of human contributions to climate change peaked again in 1957, which was declared the 'International Geophysical Year' by the International Council of 


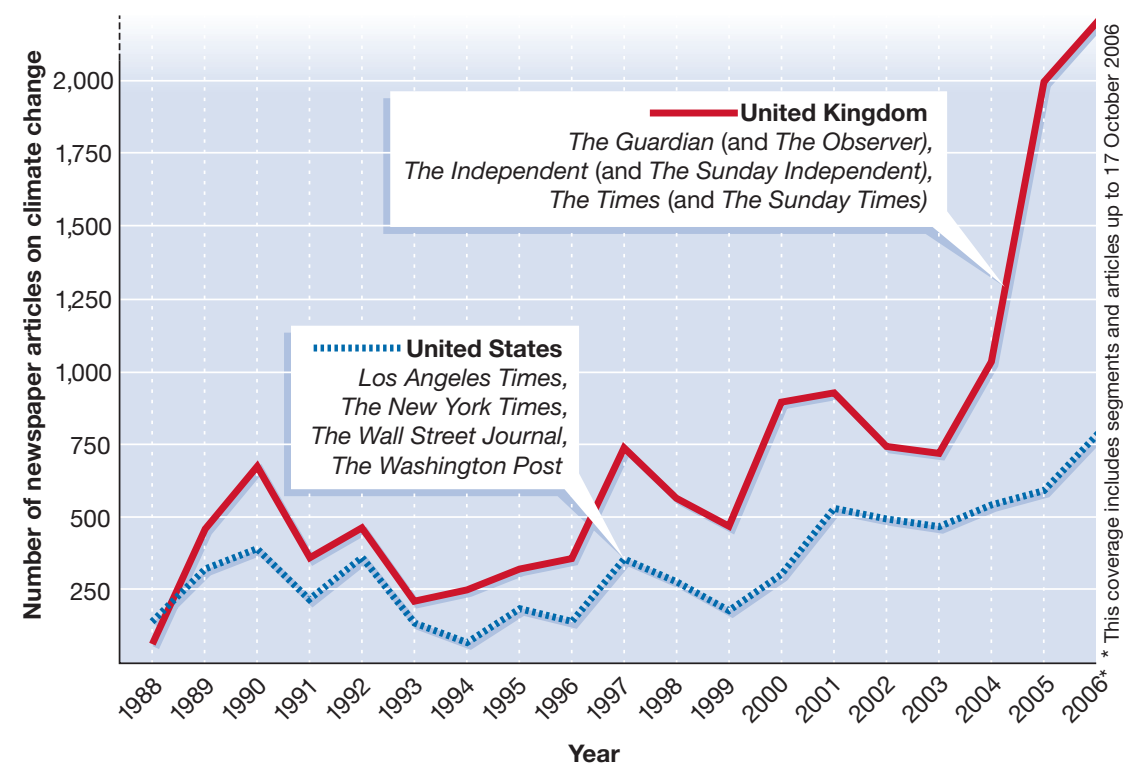

Fig1| Newspaper coverage of climatechange in theUSA and theUK.

Scientific Unions. US science reporter Robert C. Cowen wrote an article for the Christian Science Monitor called 'Are Men Changing the Earth's Weather?' (Cowen, 1957).

In the following two decades, media coverage of climate science remained sparseonly a few articles were published in newspapers in the USA and the UK throughout the 1960s and 1970s. As international and domestic climate policy gained greater cohesion in the mid-1980s through activities by, for example, the United Nations Environment Programme and the World Meteorological O rganization, an increase in media coverage followed.

\section{... theintersection of mass media, science and policy is a particularly dynamic arena of communication, in which all sides have high stakes}

The three spheres of media, science and policy finally intersected prominently in 1988 (Fig 1) when several factors contributed to a rise in media coverage both in the USA and the UK (Boykoff \& Boykoff, 2004; Carvalho, 2005). Among them was UK Prime Minister Margaret Thatcher's emphatic statement to the Royal Society of London that it was possible that with climate change, "we have unwittingly begun a massive experiment with the system of the planet itself" (Leggett, 2001). Across the Atlantic, NASA scientist James Hansen testified to US Congress that he was $99 \%$ certain "that warmer temperatures were caused by the burning of fossil fuels and not solely a result of natural variation" (Shabecoff, 1988). These statements generated substantial media coverage, and thus signified public concern for anthropogenic climate change. Overall, "what rendered 1988 so extraordinary was concatenating physical impacts felt by the person in the street" (Ungar, 1992). At the same time, multinational media corporations underwent further consolidation through mergers and acquisitions, which led to globalized media conglomerates characterized by increased corporate concentration and hypercommercialism (Bagdikian, 2004; Doyle, 2002; McChesney, 1999).

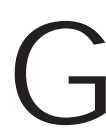
iven the potentially enormous political, social and economic implications of climate change and the strategies to slow or mitigate its potential effects, it comes as no surprise that many individuals and organizations have tried to influence media coverage of the topic. It is interesting, for example, that the US media coverage has been more critical of the opinion of the majority of scientists, namely that anthropogenic release of carbon dioxide and other greenhouse gases into the atmosphere is causing a rise in average global temperatures. This more critical reporting was not as prominent in the UK as in the USA.

It is therefore instructive to consider two external factors that might influence media coverage of this topic: frontier/expansionary mindsets and scepticism/contrarianism. Although a greater appreciation of the environment has evolved in the past 50 years in both the USA and the UK, historically entrenched cultural preoccupations with free markets and economic growthalong with the concomitant politics of interest groups-has also caused an attitude of denial that has strengthened scepticism of scientific claims about environmental decline and, more specifically, anthropogenic climate change.

The UK and the USA have shared a commitment to economic freedom for more than two centuries. British colonialists, for the most part, looked on natural resources as inexhaustible treasure chests. For example, forests were viewed either as timber mines or as an obstruction to agriculture and therefore a limiting factor to increasing revenue. Consequently, in many parts of the British empire, efforts were made to sell forests to private developers, with a few reserved for the production of timber for public works. A similar frontier and expansionistmindset in the USA took it for granted that nature and natural resources could be exploited without fear of exhaustion.

\section{Even when there is sufficient consensus over data and models, scepticism is induced either by manufacturing opposing facts or by conflating facts with values}

The commitment to economic growth based on the exploitation of natural resources, combined with a deeply entrenched technological optimism, has significantly influenced the wider policy climate. Furthermore, the interests of carbon-based industries in both countries have exerted asymmetrical power over public policy. However, the extent to which these factors have gained influence differs. Its long history, the power of traditional cultural institutions and a more constrained physical geography arguably have shaped public perception in the UK towards preservation of the environment. Conversely, an emphasis on economic 
freedom through liberal democracies, and stronger personal consumption patterns have influenced the actions and expectations of US citizens (Starr, 2004). These attitudes towards the environment and energy consumption have manifested different political actions: the UK has ratified the Kyoto Protocol, which calls for a reduction in carbon dioxide emissions, whereas the USA, the world's biggest producer of carbon dioxide, has so far refused to do likewise.

\section{... a lack of training among journalists, and a lack of timeto investigate astory and its background can thereforeact detrimentally to thetranslation of scienceinto information}

A second cultural trait that influences public attitudes to climate change in the USA and the UK is a deeply entrenched scepticism toward scientific claims of an environmental decline. Members of the UK scientific community have been trying to raise the public's and politicians' awareness of environmental decline as long ago as the first half of the nineteenth century. However, the environment has always enjoyed a rather low priority, and civil administrators have raised sceptical objections to such claims of environmental decline.

M ore specific to the issue of climate change, the interface of climate science, media and policy has become an increasingly politicized arena since the late 1980s. Many factors fuelled an atmosphere of contention in both countries, which was characterized by the emergence in the early 1990s of a group of 'climate contrarians', who were often funded by carbon-based industries (Boykoff \& Boykoff, 2004; Gelbspan, 1998). This group-also dubbed 'climate sceptics' or the 'carbon club'-have gained significant discursive traction through the media and, as a result, have affected public understanding of the issue.

These dissenters have been more prominent in the USA in part because many come from US universities or think-tanks. They have also earned privileged access to various influential US policy-makers who deal with climate change, perhaps owing in part to a confluence of interests and objectives.
Research by McCright and Dunlap examined how these individuals and groups developed competing discourses to disempower respected climate scientists. They have also tracked how they worked to reframe climate science and related policy issues with greater uncertainty, therefore breeding greater public confusion (MCCright \& Dunlap, 2000, 2003; McCright, 2007). But it was not only scientists who influenced media coverage-non-scientific critics also had a role. In a speech on the US Senate floor in 2003, Republican Senator James Inhofe, former Chair of the Environment and Public Works Committee, called climate change "the greatest hoax ever perpetrated on the American people". In 2004, author Michael Crichton wrote State of Fear, a fictional book about an environmental terrorist group, and challenged the idea of anthropogenic climate change; he was then invited to the White House to discuss climate policy with President George W. Bush. Through the media coverage, the views of Inhofe and Crichton have significantly shaped public perception as well as climate policy debates.

These external factors have influenced media coverage of science. Scepticism, a historically healthy practice in science, has been invoked by opponents of environmental science to question results and interpretations from climate researchers. The basis of these attacks on climate science is similar to that of other environmental contexts: the fact that theories are often not sufficiently supported by experimental or observational data. Indeed, it is good practice in science to demand more and better verisimilitude; how ever, when it comes to environmental or public health, demanding 'sound science' often clashes with the ethics of inaction (Shrader-Frechette, 1993). Even when there is sufficient consensus over data and models, scepticism is induced either by manufacturing opposing facts or by conflating facts with values. Consequently, journalists are often faced with a scenario that has seemingly contrary-and in some cases, contradictory-facts, and vastly varying analytical frameworks.

A gainst this background, journalists make decisions in the context of more mundane pressures, such as constraints on time until deadlines or available space within a predominantly corporate-controlled media environment (Bagdikian, 2004). Norms, values and pressures within journalistic communities and traditions also shape the media coverage of scientific topics. Some factors, such as attempts to affect public discourse through the media, are more apparent, while others-such as a journalist's background and training-are rather subtle. In addition, economic constraints and a shift towards entertainment or 'infotainment' have led to a decrease in investigative journalism (McChesney, 1999), and more journalists now work as generalists rather than specialists (Bennett, 2002). In reporting on climate science, a lack of training among journalists, and a lack of time to investigate a story and its background can therefore act detrimentally to the translation of science into information (M cComas \& Shanahan, 1999; Wilson, 2000).

\section{... media researchers have asserted that balance is often "a surrogate for validity checks"...}

In this mixture of pressures and influences, many challenges to media coverage of climatic science-along with many associated factors-gain salience. For example, there is the issue of language and translation. Some of the challenges of reporting on climate change are inherent to the differences in language - in both lexicon and usage- between science and the public. Scientists tend to speak in cautious language when describing their research, and to discuss implications of their research in terms of probabilities. For journalists and policy-makers, this is difficult to translate into the crisp, unequivocal commentary that is often valued in communications and decision-making. Malcolm Hughes, a climate scientist at the University of Arizona, USA, commented in an interview: "O n one hand, the users of scientific information ... nurture this happy illusion of hard scientific facts and take that too far ... on the other hand, we scientists in most cases will emphasize the condition clauses in any sentence because if you are close to the issue, you are aware of the scientific uncertainties in any statement that you make. Now that is a pretty bad combination if you put those two together! Because all the culture of the university and scientific societies is to hedge everything ... we are a little too unwilling to say [crisp and clear] things as we see [them]." 
$\mathrm{F}$ urthermore, journalistic norms themselves have affected the content of news stories on climate change, sometimes to the impediment of improved communication between climate science and policy (Boykoff \& Boykoff, 2007). These norms, such as 'objectivity', 'neutrality', 'impartiality' and 'balance', have emerged as standards of professional journalism in the twentieth century; the great American writer and journalist Walter Lippman in particular pushed for the development and use of such standards and norms (Carey, 1989).

\section{... if the process of media framing [... ] confuses rather than clarifies scientific understanding, it creates opportunities for policy-makers to defray responsibility and delay action}

Among these practices, the norm of 'balanced reporting' has had a rather detrimental effect on the media coverage of climate science and other scientific topics in the USA (Boykoff \& Boykoff, 2004). Balance has been deemed a crucial tool for neutral or objective reporting, by providing "both sides in any significant dispute with roughly equal attention" (Entman, 1993). However media researchers have asserted that balance is often "a surrogate for validity checks", because "the typical journalist, even one trained as a science writer, has neither the time nor the expertise to check the validity of claims" (Dunwoody \& Peters, 1992). As Chris Mooney pointed out, this can actually lead to unbalanced reporting if the article gives undue space and attention to views held by only a tiny minority of the scientific community (Mooney, 2004). For the reader or viewer, this creates the impression that the sceptics have a valid point, and that the topic at hand remains disputed and therefore unproven. Indeed, inserting scientific uncertainty into the discourse raises the perception of debate (Zehr, 2000; Wilkins, 1993), despite the fact that the vast majority of scientists support the claim that we are witnessing a rapid change in global weather patterns. This has important repercussions on public policy: if the process of media framing-whereby the bounds of discourse and meanings are constructed and reinforced-confuses rather than clarifies scientific understanding, it creates opportunities for policy-makers to defray responsibility and delay action.

Furthermore, critics of the mainstream scientific view - that human action causes a change in global climate-have tried to use balanced reporting and other journalistic norms to influence media coverage, in particular in the USA. In the summer of 2006, a memo leaked from the Intermountain Rural Electric Association (Sedalia, CO, USA), an electricity distribution cooperative that owns coal-burning power plants, revealed that the group had funded a long-time sceptic of anthropogenic climate change (Sandell \& Blakemore, 2006). Although the funding is not illegal, it has raised ethical questions as the message behind the donation flies in the face of scientific understanding. 0 ther carbon-based industry groups have staged media campaigns: the Competitive Enterprise Institute, a Washington, DCbased public policy organization-"dedicated to advancing the principles of free enterprise and limited government", according to their website-assembled a set of commercials in 2006 that targeted 13 key cities in the U SA, asserting that carbon dioxide is not a pollutant. Their slogan was 'W e Call It Life' (CEI, 2006).

\section{... journalism and public concerns haveshaped decisionsin climate science and policy, just as climate scienceand policy haveshaped media reporting and public understanding}

In 1998, the N ew York Times revealed that opponents of international climate policy had put together a plan with a U $\$ \$ 600,000$ budget to recruit scientists "who share the industry's views of climate science and to train them in public relations so they can help convince journalists, politicians, and the public that the risk of global warming is too uncertain to justify controls on greenhouse gases..." (Cushman, 1998). This plan-assembled at the American Petroleum Institute offices in Washington, DC, USA - targeted science writers, editors, columnists and television network correspondents in order to affect media discourse on the human contribution to climate change. The proposal of the group stated that it would measure success "by counting, among other things, the percentage of news articles that raise questions about climate science and the number of radio talk show appearances by scientists questioning the prevailing views".

In discussing the influence of the mass media, W. Lance Bennett stated, "Few things are as much a part of our lives as the news ... [it] has become a sort of instant historical record of the pace, progress, problems, and the hopes of society" (Bennett, 2002). The story of climate science and its coverage by the media is no exception: journalism and public concerns have shaped decisions in climate science and policy, just as climate science and policy have shaped media reporting and public understanding. It is therefore instructive to analyse the intersecting and diverging factors that influence media coverage of climate science in the USA and the UK to understand better the terms and conditions through which policy is negotiated and action is taken. Such considerations can provide insights into many other important topics, such as genetically modified organisms, the safety of vaccines or the ethics of stem-cell research. Central to each of these debates is the understanding and analysis of how the facts and values intertwine. Equally important is the question of how to weigh future potential risks and costs against tangible economic benefits for the presentsomething that is at the very heart of both the social science and policy communities.

\section{REFERENCES}

Abarbanel A, McClusky T (1950) Is the world getting warmer? Saturday Evening Post,

1 Jul, p22

Bagdikian BH (2004) The N ew Media Monopoly. Boston, MA, USA: Beacon

Bennett WL (2002) N ews: The Politics of Illusion, 5th edition. N ew York, NY, U SA: Longman Boykoff MT, Boykoff JM (2004) Balance as bias: global warming and the US prestige press. Glob Environ Change 14: 125-136

Boykoff M T, Boykoff JM (2007) Climate change and journalistic norms: A case study of U.S. mass-media coverage. Geoforum (in press)

Carey JW (1989) Communication as Culture:

Essays on Media and Society. Boston, MA, USA: Unwin Hyman

Carvalho A (2005) Representing the politics of the greenhouse effect: Discursive strategies in the British media. Critical D iscourse Studies 2: 1-29

CEl (2006) We Call it Life. Washington, DC, USA: Competitive Enterprise Institute

Cowen RC (1957) Are men changing the earth's weather? Christian Science M onitor, 4 Dec, p13

Cushman JH (1998) Industrial group plans to battle climate treaty. $\mathrm{N}$ ew York Times, $26 \mathrm{Apr}, \mathrm{p} 1$ 
Doyle G (2002) M edia O wnership: The Economics and Politics of Convergence and Concentration in the UK and European Media. London, U K: Sage Publications

Dunwoody S, Peters H P (1992) M ass media coverage of technological and environmental risks: A survey of research in the U nited States and Germany. Public Underst Sci 1: 199-230

Entman RM (1993) Framing: toward clarification of a fractured paradigm. J Commun 43: 51-58 Fleming JR (1998) H istorical Perspectives on Climate Change. O xford, U K: O xford U niversity Press

Gelbspan R (1998) The Heat Is O n. Cambridge, MA, U SA: Perseus Books

Grove RH (2003) Green Imperialism. Cambridge, UK: Cambridge U niversity Press

LeggettJ (2001) The Carbon War. N ew York, NY, USA: Routledge

McChesney RW (1999) Rich Media, Poor Democracy: Communication Politics in Dubious Times. U rbana, IL, USA: U niversity of Illinois Press

McComas K, Shanahan J (1999)Telling stories about global climate change: M easuring the impact of narratives on issue cycles. Communic Res 26: 30-57

McCright AM (2007) D ealing with climate change contrarians. In M oser SC, Dilling L (eds) Creating a Climate for Change: Communicating Climate Change and Facilitating Social Change, pp 200-212. Cambridge, UK: Cambridge University Press
McCright AM, Dunlap RE (2000) Challenging global warming as a social problem: An analysis of the conservative movement's counter-claims. Soc Probl 47: 499-522

McCright AM, Dunlap RE (2003) D efeating Kyoto: The conservative movement's impact on U.S. climate change policy. Soc Probl 50: 348-373

Mooney C (2004) Blinded by science. Columbia Journalism Review 6(Nov/Dec), www.cjr.org

NSF (2004) Science \& Engineering Indicators 2004. Washington, DC, USA: N ational Science Foundation

Project for Excellence in Journalism (2006) The State of the N ews M edia 2006. Washington, DC, USA: Project for Excellence in Journalism. www.stateofthenewsmedia.org

Rajan SR (2006) M odernizing N ature. O xford, UK: 0 xford U niversity Press

Sandell C, Blakemore B (2006) ABC N ews reporting cited as evidence in congressional hearing on global warming. ABC N ews, 27 Jul, http://abcnews.go.com

Shabecoff P (1988) G lobal warming has begun, expert tells senate. N ew York Times, 24 Jun, pA1

Shrader-Frechette KS (1993) Burying U ncertainty. Berkeley, CA, USA: U niversity of California Press

Starr P (2004) The Creation of the M edia: Political $O$ rigins of M odern Communications. N ew York, NY, USA: Basic Books

Ungar S (1992)The rise and (relative) decline of global warming as a social problem. Sociol Q 33: 483-501
Weart SR (2003) The Discovery of G lobal Warming. Cambridge, MA, USA: Harvard U niversity Press

W eingart P, Engels A, Pansegrau P (2000) Risks of communication: Discourses on climate change in science, politics, and the mass media. Public Underst Sci 9: 261-283

Wilkins L (1993) Between the facts and values: Print media coverage of the greenhouse effect, 1987-1990. Public Underst Sci 2: 71-84 Wilson KM (1995) Mass media as sources of global warming knowledge. Mass Communication Review 22: 75-89

Wilson KM (2000) Communicating climate change through the media: Predictions, politics, and perceptions of risks. In Allan S, Adam B, Carter C (eds) Environmental Risks and the Media, pp 201-217. New York, NY, U SA: Routledge

Zehr SC (2000) Public representations of scientific uncertainty about global climate change. Public Underst Sci 9: 85-103

\section{Maxwell T. Boykoff is a James Martin Research Fellow at 0 xford University Centre for the Environment, 0 xford, UK. \\ E-mail: maxwell.boykoff@ouce.ox.ac.uk S. Ravi Rajan is an AssociateProfessor of Environmental Studiesand CollegeEight Provost at theUniversity of California-Santa Cruz, CA, USA. E-mail: srrajan@ucsc.edu}

doi:10.1038/sj.embor.7400924 